Article

\title{
Identification of Volatile Components of Liverwort (Porella cordaeana) Extracts Using GC/MS-SPME and Their Antimicrobial Activity
}

\section{Danka Bukvicki ${ }^{1,2, *}$, Davide Gottardi ${ }^{2}$, Milan Veljic ${ }^{1}$, Petar D. Marin ${ }^{1}$, Lucia Vannini ${ }^{2}$ and Maria Elisabetta Guerzoni ${ }^{2}$}

1 Institute of Botany and Botanical Garden "Jevremovac", Faculty of Biology, University of Belgrade, Studentski trg 16, 11000 Belgrade, Serbia; E-Mails: veljicm@bio.bg.ac.rs (M.V.); pdmarin@bio.bg.ac.rs (P.D.M.)

2 Department of Food Science, University of Bologna, Via Fanin 46, 40127 Bologna, Italy; E-Mails: da.gottardi@gmail.com (D.G.); lucia.vannini2@unibo.it(L.V.); elisabetta.guerzoni@unibo.it (M.E.G.)

* Author to whom correspondence should be addressed; E-Mails: dankabukvicki@bio.bg.ac.rs or dankabukvicki@gmail.com; Tel.: +381-64-206-5264; Fax: +38-111-324-3603.

Received: 7 May 2012; in revised form: 29 May 2012 / Accepted: 1 June 2012 /

Published: 6 June 2012

Abstract: Chemical constituents of liverwort (Porella cordaeana) extracts have been identified using solid-phase microextraction-gas chromatography mass spectrometry (SPME-GC/MS). The methanol, ethanol and ethyl acetate extracts were rich in terpenoids such as sesquiterpene hydrocarbons $(53.12 \%, 51.68 \%, 23.16 \%)$, and monoterpene hydrocarbons $(22.83 \%, 18.90 \%, 23.36 \%)$, respectively. The dominant compounds in the extracts were $\beta$-phellandrene $(15.54 \%, 13.66 \%, 12.10 \%)$ and $\beta$-caryophyllene $(10.72 \%$, $8.29 \%, 7.79 \%$, respectively). The antimicrobial activity of the extracts was evaluated against eleven food microorganisms using the microdilution and disc diffusion methods. The minimum inhibitory concentration (MIC) varied from 0.50 to $2.00 \mathrm{mg} / \mathrm{mL}$ for yeast strains (Saccharomyces cerevisiae 635, Zygosacharomyces bailii 45, Aerobasidium pullulans L6F, Pichia membranaefaciens OC 71, Pichia membranaefaciens OC 70, Pichia anomala CBS 5759, Pichia anomala DBVPG 3003 and Yarrowia lipolytica RO13), and from 1.00 to $3.00 \mathrm{mg} / \mathrm{mL}$ for bacterial strains (Salmonella enteritidis 155, Escherichia coli 555 and Listeria monocytogenes 56Ly). Methanol extract showed better activity in comparison with 
ethanol and ethyl acetate extracts. High percentages of monoterpene and sesquiterpene hydrocarbons could be responsible for the better antimicrobial activity.

Keywords: liverwort; Porella cordaeana; GC/MS-SPME; antimicrobial activity; food microorganisms

\section{Introduction}

Bryophytes possess some bioactive components and therefore are used throughout the World as drugs and remedies to cure various diseases [1]. They have been proven to be rich sources of antimicrobials, and attempts to find potent, nontoxic, broad-spectrum active molecules have been widely undertaken. Liverwort extracts with antimicrobial effects are even sold commercially [2]. They are used in pharmaceutical products, horticulture and good indicators of environmental conditions.

Phytochemical studies of liverworts have shown that they contain a wide variety of structurally interesting compounds, some of which are antibacterial, antifungal, anticancer and diuretic agents [3]. Liverworts contain a large amount of mono-, sesqui- and diterpenoids, and aromatic compounds. In particular, they contain pinguisane-type sesquiterpenoids, sacculatane-type diterpenoids and bis(bi-benzyl) aromatic compounds which have not been found in higher plants [4].

Previous studies on the chemical composition of liverworts revealed that they often produce unique sesquiterpenoids with novel carbon skeletons, which are not isolated from vascular plants, and most of the sesquiterpenoids from liverworts correspond to enantiomers of those from higher plants. On the other side, a large variety of sesquiterpene hydrocarbons are important intermediates in the biosynthesis of functionalized sesquiterpenes, which may be useful reference compounds [5].

The cosmopolitan liverwort genus Porella, consisting of some 50-60 species, is widely distributed in temperate areas. Porella L. is characterised by bilobed, incubously inserted leaves with a vestigial, often recurved keel, large underleaves that are similar to the lobules in shape, terminal gynoecia on short lateral branches, large, flattened perianths, and a capsule that is barely exerted from the perianth and dehisces into numerous irregular valves [6].

In earlier work, volatile components and pinguisane-type sesquiterpenoids from American samples of Porella cordaeana were reported [7]. Three new pinguisane-type sesquiterpenoids, i.e., porellapinguisanolide, porellapinguisenone and spiropinguisanin have been isolated, together with the previously known pinguisanin, norpinguisone methyl ester, striatenone and squalene. In more recent articles, it has been shown that the Porella species are also a rich source of terpenoid natural products including a range of pinguisanes [8]. Most Porella species are rich sources of sesqui- and diterpenoids, many of which show interesting biological activities [9]. Fifteen Porella species have been divided into nine types, drimane-aromadendrane-pinguisane-type (type I), sacculatane-type (II), pinguisanetype (III), pinguisane-sacculatane-type (IV), africanane-type (V), santalane-africanane-cyclofarnesanetype (VI), guaiane-type (VII), germacrane-pinguisane-sacculatane-type (VIII) and germacraneafricanane-guaiane-type (IX) [3]. P. cordaeana (type IV), collected in Europe produces mainly striatanes and pinguisanes and sacculatanes [3]. 
To the best of our knowledge there are no reports on the GC/MS-SPME analysis and antimicrobial properties of the extracts from the liverwort $P$. cordaeana. The aim of this study was to analyze volatile compounds of different extracts of $P$. cordaeana by using the GC/MS-SPME technique and evaluate the extracts' activity against important food spoilage and potential pathogenic microorganisms.

\section{Results and Discussion}

\subsection{GC/MS-SPME Analysis of the Chemical Composition of the Extracts}

Qualitative and quantitative analysis of extracts are listed in Table 1. Among the groups, sesquiterpene hydrocarbons predominated $(53.12 \%, 51.68 \%, 23.16 \%)$, followed by monoterpene hydrocarbons $(22.83 \%, 18.90 \%, 23.36 \%)$, non-terpene hydrocarbons $(0.57 \%, 0.96 \%, 42.90 \%)$ and alcohols $(5.32 \%, 18.34 \%, 3.54 \%)$ in methanol, ethanol and ethyl acetate extracts, respectively.

Table 1. Chemical composition of $P$. cordaeana extracts.

\begin{tabular}{|c|c|c|c|c|}
\hline Extract & & ${ }^{\mathrm{a}} \mathrm{MeOH}$ & ${ }^{\mathrm{b}} \mathrm{EtOH}$ & ${ }^{\mathrm{c}}$ EtOAc \\
\hline Compounds & RI & $\%$ & $\%$ & $\%$ \\
\hline \multicolumn{5}{|c|}{ Monoterpene hydrocarbons } \\
\hline Camphene & 1077 & 0.11 & 0.10 & 0.33 \\
\hline$\beta$-Myrcene & 1167 & 0.00 & 0.00 & 1.46 \\
\hline$\alpha$-Phellandrene & 1177 & 0.84 & 0.40 & 1.37 \\
\hline D-Limonene & 1208 & 3.68 & 2.93 & 3.31 \\
\hline$\beta$-Phellandrene & 1220 & 15.54 & 13.66 & 12.10 \\
\hline$m$-Cymene & 1267 & 2.66 & 1.81 & 1.68 \\
\hline p-Cymene & 1280 & 0.00 & 0.00 & 3.11 \\
\hline Totals: & & 22.83 & 18.90 & 23.36 \\
\hline \multicolumn{5}{|c|}{ Sesquiterpene hydrocarbons } \\
\hline$\alpha$-Cubebene & 1463 & 0.11 & 0.10 & 0.00 \\
\hline$\delta$-Elemene & 1472 & 0.38 & 0.22 & 0.00 \\
\hline$\beta$-Himachalene & 1498 & 0.53 & 0.17 & 0.00 \\
\hline Cycloseychellene & 1513 & 3.87 & 4.45 & 2.87 \\
\hline$\alpha$-Farnesene & 1524 & 0.42 & 0.47 & 0.00 \\
\hline$\beta$-Cubebene & 1531 & 0.31 & 0.46 & 0.00 \\
\hline$\beta$-Humulene & 1538 & 0.64 & 0.63 & 0.00 \\
\hline$\alpha$-Longipinene & 1552 & 0.64 & 0.88 & 0.00 \\
\hline$\alpha$-Santalene & 1557 & 0.98 & 1.14 & 0.18 \\
\hline$\beta$-Elemene & 1571 & 3.94 & 2.77 & 1.39 \\
\hline ç-Gurjunene & 1583 & 3.27 & 5.15 & 2.21 \\
\hline Neoisolongifolene & 1588 & 5.60 & 6.25 & 4.14 \\
\hline$\beta$-Cedrene & 1590 & 1.46 & 1.60 & 0.23 \\
\hline$\beta$-Caryophyllene & 1594 & 10.72 & 8.29 & 7.79 \\
\hline cis-Thujopsene & 1623 & 3.98 & 1.60 & 0.00 \\
\hline Aromadendrene & 1652 & 3.43 & 2.81 & 0.14 \\
\hline$\beta$-Farnesene & 1664 & 0.15 & 0.00 & 0.11 \\
\hline$\gamma$-Muurolene & 1671 & 3.48 & 3.68 & 2.24 \\
\hline di-epi- $\alpha$-Cedrene & 1677 & 0.44 & 0.71 & 0.00 \\
\hline Sesquichamene & 1692 & 0.44 & 0.54 & 0.00 \\
\hline
\end{tabular}


Table 1. Cont.

\begin{tabular}{|c|c|c|c|c|}
\hline Extract & & ${ }^{\mathrm{a}} \mathrm{MeOH}$ & ${ }^{\mathrm{b}} \mathrm{EtOH}$ & ${ }^{\mathrm{c}}$ EtOAc \\
\hline Compounds & RI & $\%$ & $\%$ & $\%$ \\
\hline Aciphyllene & 1701 & 0.00 & 0.14 & 0.00 \\
\hline Germacrene & 1717 & 1.10 & 0.00 & 0.22 \\
\hline Valencene & 1726 & 3.51 & 4.06 & 0.45 \\
\hline Elixene & 1746 & 0.09 & 0.16 & 0.00 \\
\hline$\alpha$-Chamigrene & 1755 & 2.36 & 2.89 & 0.24 \\
\hline$\alpha$-Curcumene & 1776 & 0.13 & 0.11 & 0.09 \\
\hline$(-)$ - $\alpha$-Panasinsene & 1784 & 1.07 & 1.21 & 0.13 \\
\hline Cuparene & 1851 & 0.00 & 1.10 & 0.08 \\
\hline Calamenene & 1855 & 0.07 & 0.00 & 0.65 \\
\hline Spathulenol & 2129 & 0.00 & 0.09 & 0.00 \\
\hline Totals: & & 53.12 & 51.68 & 23.16 \\
\hline \multicolumn{5}{|l|}{ Non-terpene hydrocarbons } \\
\hline 3-Methylnonane & 965 & 0.00 & 0.00 & 0.22 \\
\hline Decane & 984 & 0.00 & 0.00 & 2.80 \\
\hline 3,7-Dimethylnonane & 1008 & 0.00 & 0.00 & 0.67 \\
\hline 5-Methyldecane & 1037 & 0.00 & 0.00 & 1.28 \\
\hline 2-Methyldecane & 1038 & 0.00 & 0.87 & 3.69 \\
\hline 3-Methyldecane & 1048 & 0.00 & 0.00 & 3.17 \\
\hline Undecane & 1091 & 0.00 & 0.09 & 5.32 \\
\hline 2,3-Dimethyldecane & 1142 & 0.00 & 0.00 & 0.91 \\
\hline Dodecane & 1190 & 0.00 & 0.00 & 1.44 \\
\hline$m$-Ethyltoluene & 1230 & 0.00 & 0.00 & 0.67 \\
\hline Mesitylene & 1253 & 0.00 & 0.00 & 0.22 \\
\hline Hemimellitene & 1292 & 0.00 & 0.00 & 3.40 \\
\hline$m$-Diethylbenzene & 1308 & 0.00 & 0.00 & 0.31 \\
\hline$m$-Propyltoluene & 1315 & 0.00 & 0.00 & 1.05 \\
\hline$p$-Propyltoluene & 1318 & 0.00 & 0.00 & 0.40 \\
\hline Butylbenzene & 1322 & 0.00 & 0.00 & 0.31 \\
\hline 4-Ethyl-m-xylene & 1337 & 0.00 & 0.00 & 1.46 \\
\hline 1,2-Diethylbenzene & 1342 & 0.00 & 0.00 & 0.71 \\
\hline$o$-Propyltoluene & 1350 & 0.00 & 0.00 & 2.89 \\
\hline 2-Ethyl- $p$-xylene & 1368 & 0.00 & 0.00 & 3.13 \\
\hline 2-Ethyl-1,3-dimethylbenzene & 1375 & 0.57 & 0.00 & 4.32 \\
\hline Cumene & 1384 & 0.00 & 0.00 & 1.04 \\
\hline 3,5-Diethyltoluene & 1402 & 0.00 & 0.00 & 1.30 \\
\hline Durene & 1488 & 0.00 & 0.00 & 1.44 \\
\hline 5-Methylindane & 1510 & 0.00 & 0.00 & 0.45 \\
\hline 1,6-Dimethylindane & 1527 & 0.00 & 0.00 & 0.30 \\
\hline Totals: & & $\mathbf{0 . 5 7}$ & 0.96 & 42.90 \\
\hline \multicolumn{5}{|l|}{ Esters } \\
\hline Acetic acid methyl ester & 823 & 1.21 & 0.00 & 0.00 \\
\hline Pyruvic acid methyl ester & 1240 & 0.05 & 0.00 & 0.00 \\
\hline Totals: & & 1.26 & 0.00 & 0.00 \\
\hline \multicolumn{5}{|l|}{ Alcohols } \\
\hline 1-Propanol & 1037 & 0.00 & 0.46 & 0.00 \\
\hline 1-Butanol & 1142 & 0.00 & 0.09 & 0.00 \\
\hline 1-Ethoxy-2-propanol & 1168 & 0.00 & 1.46 & 0.00 \\
\hline
\end{tabular}


Table 1. Cont.

\begin{tabular}{|c|c|c|c|c|}
\hline Extract & & ${ }^{\mathrm{a}} \mathrm{MeOH}$ & ${ }^{\mathrm{b}} \mathrm{EtOH}$ & ${ }^{\mathbf{c}}$ EtOAc \\
\hline Compounds & RI & $\%$ & $\%$ & $\%$ \\
\hline 2-Methyl-1-butanol & 1202 & 0.27 & 8.24 & 0.00 \\
\hline 4-Methyl-2-pentanol & 1162 & 4.20 & 5.60 & 3.54 \\
\hline 1-Propoxy-2-propanol & 1245 & 0.20 & 1.54 & 0.00 \\
\hline 1-Hexanol & 1348 & 0.39 & 0.95 & 0.00 \\
\hline 1-Octen-3-ol & 1441 & 0.26 & 0.00 & 0.00 \\
\hline Totals: & & 5.32 & 18.34 & 3.54 \\
\hline \multicolumn{5}{|l|}{ Ketones } \\
\hline 4-Methyl-3-pentene-2-one & 1146 & 0.57 & 0.30 & 0.00 \\
\hline Methyl isobutyl ketone & 1007 & 0.75 & 0.00 & 0.00 \\
\hline Totals: & & 1.32 & 0.30 & 0.00 \\
\hline \multicolumn{5}{|l|}{ Aldehydes } \\
\hline Pentanal & 982 & 0.51 & 0.21 & 0.00 \\
\hline 2-Butenal & 1049 & 0.00 & 0.09 & 0.00 \\
\hline 2-Methyl-1-propanal & 1092 & 0.00 & 0.17 & 0.00 \\
\hline Hexanal & 1097 & 0.99 & 0.52 & 0.00 \\
\hline Totals: & & 1.50 & 0.99 & 0.00 \\
\hline \multicolumn{5}{|l|}{ Others } \\
\hline 2-Pentylfuran & 1235 & 0.05 & 0.00 & 0.00 \\
\hline Acetic acid & 1448 & 8.02 & 4.77 & 5.57 \\
\hline Propanoic acid & 1519 & 3.73 & 2.29 & 0.00 \\
\hline Hexanoic acid & 1861 & 0.34 & 0.22 & 0.00 \\
\hline Totals: & & 12.14 & 7.28 & 5.57 \\
\hline Unidentified & & 1.94 & 1.55 & 1.47 \\
\hline Total identified \% & & 98.06 & 98.45 & 98.53 \\
\hline
\end{tabular}

Esters, ketones and aldehydes were present in amounts lower than 3.00\%. Forty-eight components were identified from the methanol extract of $P$. cordaeana, representing $98.06 \%$ of the total extract, and major compounds were $\beta$-phellandrene (15.54\%), $\beta$-caryophyllene $(10.72 \%)$ and acetic acid $(8.02 \%)$. Forty-seven components were identified from the ethanol extract, representing $98.45 \%$ of the total extract, and $\beta$-phellandrene (13.66\%), $\beta$-caryophyllene (8.29\%), 2-methyl-1-butanol (8.24\%), neoisolongifolene $(6.25 \%)$ and ç-Gurjunene $(5.15 \%)$ were the major components. $\beta$-phellandrene (12.10\%), $\beta$-caryophyllene (7.79\%), undecane (5.32\%), acetic acid (5.57\%), D-limonene (3.31\%), neoisolongifolene (4.14\%) and $p$-Cymene (3.11\%) were the main compounds in the ethyl acetate extract.

In the methanol extract $53.12 \%$ sesquiterpene hydrocarbons, $23.83 \%$ monoterpene hydrocarbons, $1.26 \%$ esters, $1.32 \%$ ketones and $5.32 \%$ alcohols were present. However, $1.94 \%$ of total compounds were not identified. In the $P$. cordaeana ethanol extract $51.68 \%$ sesquiterpene hydrocarbons, $18.90 \%$ monoterpene hydrocarbons, $0.30 \%$ ketones and $18.34 \%$ alcohols were identified, while in the ethyl acetate $23.16 \%$ sesquiterpene hydrocarbons, $23.36 \%$ monoterpene hydrocarbons, $42.90 \%$ non-terpene hydrocarbons and 3.54\% alcohols were detected (Figure 1). 
Figure 1. The chemical class distribution of the $P$. cordaeana extracts.

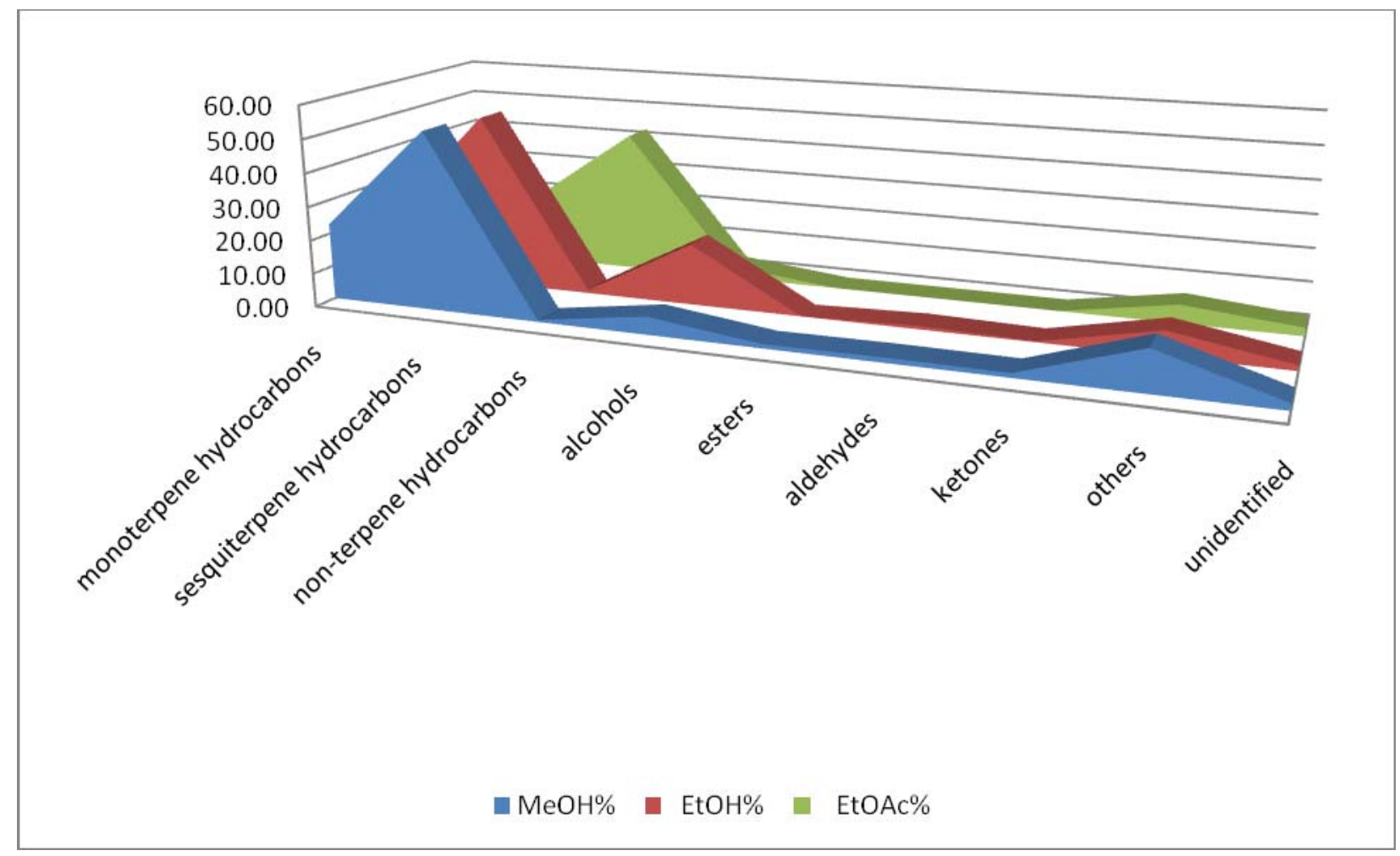

Several researchers have also reported that some Porella species contained sesquiterpenes [9-15].

\subsection{Antimicrobial Activity}

According to the results given in Table 2, all three extracts of $P$. cordaeana showed inhibition effects on the growth of all the strains tested. In particular, a notable antimicrobial activity was observed against all the strains of the tested yeasts species, which were more sensitive than bacteria to the effect of the extracts. For the yeast strains the MIC varied from $0.50 \mathrm{mg} / \mathrm{mL}$ to $2.00 \mathrm{mg} / \mathrm{mL}$, while MFC varied from $1.00 \mathrm{mg} / \mathrm{mL}$ to $3.00 \mathrm{mg} / \mathrm{mL}$. The most sensitive yeast was Yarrowia lipolytica RO13 with a MIC of $0.50-1.00 \mathrm{mg} / \mathrm{mL}$ and a MFC of $1.5 \mathrm{mg} / \mathrm{mL}$. Zygossacharomyces bailii 45 (MIC of $1.50-2.00 \mathrm{mg} / \mathrm{mL}$ and MFC of $3.00 \mathrm{mg} / \mathrm{mL}$ ) and P. membranaefaciens $O C 70$ (MIC $2.00 \mathrm{mg} / \mathrm{mL}$ and MFC $2.50 \mathrm{mg} / \mathrm{mL}$ ) were the most resistant ones to the extracts tested. The strongest anti-yeast activity was displayed by the methanol extract of $P$. cordaeana. Commercial antibiotic cycloheximide showed inhibition for concentrations lower than $0.05 \mathrm{mg} / \mathrm{mL}$ for all micromycetes except against $Y$. lipolytica $R O 13$ that was completely inhibited at $0.02 \mathrm{mg} / \mathrm{mL}$ (Table 2). The methanol extract exhibited the highest activity against $Y$. lipolytica RO13. In general the methanol extract was the most effective against all the strains (bacteria and yeasts). Methanol extract contained high amount $(8.02 \%)$ of acetic acid which has shown excellent bactericidal effect [16]. 
Table 2. Antimicrobial activity of $P$. cordaeana methanol, ethanol and ethyl acetate extracts $(\mathrm{mg} / \mathrm{mL})$.

\begin{tabular}{lccccccc}
\hline $\begin{array}{l}\text { Liverwort } \\
\text { Extracts }\end{array}$ & \multicolumn{2}{c}{$\begin{array}{c}\text { P. cordaeana } \\
\text { MeOH extract }\end{array}$} & $\begin{array}{c}\text { P. cordaeana } \\
\text { EtOH extract }\end{array}$ & $\begin{array}{c}\text { P. cordaeana } \\
\text { EtOAc extract }\end{array}$ & Cycloheximide \\
\hline Yeast & MIC & MFC & MIC & MFC & MIC & MFC & MIC \\
S. cerevisiae 635 & 1.25 & 2.00 & 1.50 & 2.00 & 1.50 & 2.00 & $<0.05$ \\
Z. bailii 45 & 2.00 & 3.00 & 1.50 & 3.00 & 1.50 & 3.00 & $<0.05$ \\
A. pullulans L6F & 1.00 & 1.50 & 1.00 & 2.00 & 1.00 & 2.00 & $<0.05$ \\
P.membranaefaciens OC 71 & 1.25 & 2.00 & 2.00 & 2.50 & 2.00 & 2.50 & $<0.05$ \\
P. memb. OC 70 & 2.00 & 2.50 & 2.00 & 2.50 & 2.00 & 2.50 & $<0.05$ \\
P. anomala CBS 5759 & 1.00 & 1.50 & 1.00 & 1.50 & 1.00 & 1.50 & $<0.05$ \\
P. anomala DBVPG 3003 & 1.75 & 2.00 & 1.75 & 2.00 & 1.25 & 2.00 & $<0.05$ \\
Yarrowia lipolytica RO13 & 0.50 & 1.50 & 0.50 & 1.00 & 1.00 & 1.50 & 0.02 \\
\hline
\end{tabular}

MIC: Minimal inhibitory concentration; MFC: Minimal microbicidal concentration.

Data relative to the antibacterial effects of $P$. cordaeana are presented in Table 3 . The data showed the higher antimicrobial efficacy of methanol extract than the other two. MIC ranged between 1.00-3.00 $\mathrm{mg} / \mathrm{mL}$, while MBC was $1.50-3.00 \mathrm{mg} / \mathrm{mL}$. The most sensitive bacterium was Listeria monocytogenes 56Ly. In particular, the methanol extract of $P$. cordaeana presented a MIC of $1.00 \mathrm{mg} / \mathrm{mL}$ against L. monocytogenes 56Ly. Furthermore, the growth of L. monocytogenes 56Ly was completely inhibited at $1.50 \mathrm{mg} / \mathrm{mL}$ for the methanol extract. The most resistant bacterial strain was E. coli 555 with a MIC of $2.00-3.00 \mathrm{mg} / \mathrm{mL}$ and $\mathrm{MBC}$ of $3.00 \mathrm{mg} / \mathrm{mL}$. MIC for streptomycin was $0.02-0.05 \mathrm{mg} / \mathrm{mL}$ and $\mathrm{MBC} 0.1 \mathrm{mg} / \mathrm{mL}$. According to the MICs and MBCs, the Gram-negative bacterial strains were more resistant than the Gram-positive one. S. enteritidis 155 and E. coli 555 (Gram-negative) showed MICs of $1 \mathrm{mg} / \mathrm{mL}, 2.00 \mathrm{mg} / \mathrm{mL}$ and MBCs of $2.00 \mathrm{mg} / \mathrm{mL}, 3.00 \mathrm{mg} / \mathrm{mL}$ respectively, for the methanol extract. Nevertheless, it should be taken into consideration that quite a high variability could be found in the sensitivity to antimicrobials among strains of the same microbial species.

Table 3. Antibacterial activity of $P$. cordaeana methanol, ethanol and ethyl acetate extracts $(\mathrm{mg} / \mathrm{mL})$.

\begin{tabular}{lcccccccc}
\hline $\begin{array}{l}\text { Liverwort } \\
\text { Extracts }\end{array}$ & \multicolumn{2}{c}{$\begin{array}{c}\text { c cordeana } \\
\text { MeOH extract }\end{array}$} & \multicolumn{2}{c}{$\begin{array}{c}\text { P. cordeana } \\
\text { EtOH extract }\end{array}$} & \multicolumn{2}{c}{$\begin{array}{c}\text { P. cordeana } \\
\text { EtOAc extract }\end{array}$} & \multicolumn{2}{c}{ Streptomycin } \\
\hline Bacteria & MIC & MBC & MIC & MBC & MIC & MBC & MIC & MBC \\
S. Enteritidis $\mathbf{1 5 5}$ & 1.00 & 2.00 & 1.50 & 2.00 & 1.50 & 2.00 & 0.05 & 0.10 \\
L. monocytogenes 56Ly & 1.00 & 1.50 & 1.50 & 2.00 & 1.50 & 2.00 & 0.02 & 0.10 \\
E. coli 555 & 2.00 & 3.00 & 3.00 & 3.00 & 2.00 & 3.00 & 0.05 & 0.10 \\
\hline
\end{tabular}

MIC: Minimal Inhibitory concentration; MBC: Minimal Bactericidal concentration. 
Figure 2. Zone of inhibition (mm) due to different concentrations (20, 30 and $40 \mu \mathrm{L})$ of P. cordaeana methanol extract against the bacterial strains of $S$. Enteritidis 155, E. coli 555 and L. monocytogenes $56 L y$. Column height represents the mean of triplicate results and error bar represents the range of the results.

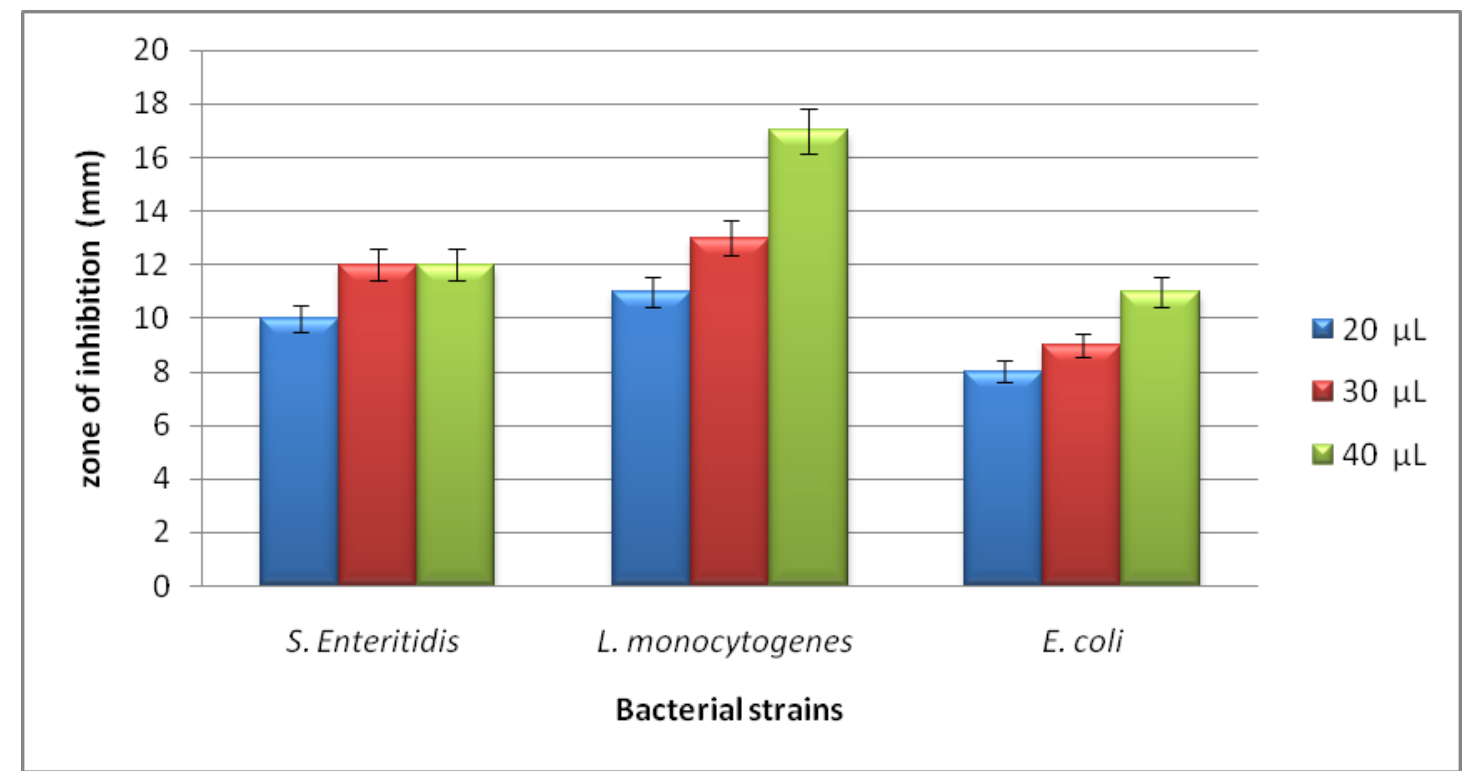

Figure 3. Zone of inhibition (mm) due to different concentrations $(20,30$ and $40 \mu \mathrm{L})$ of $P$. cordaeana methanol extract against different yeast strains.

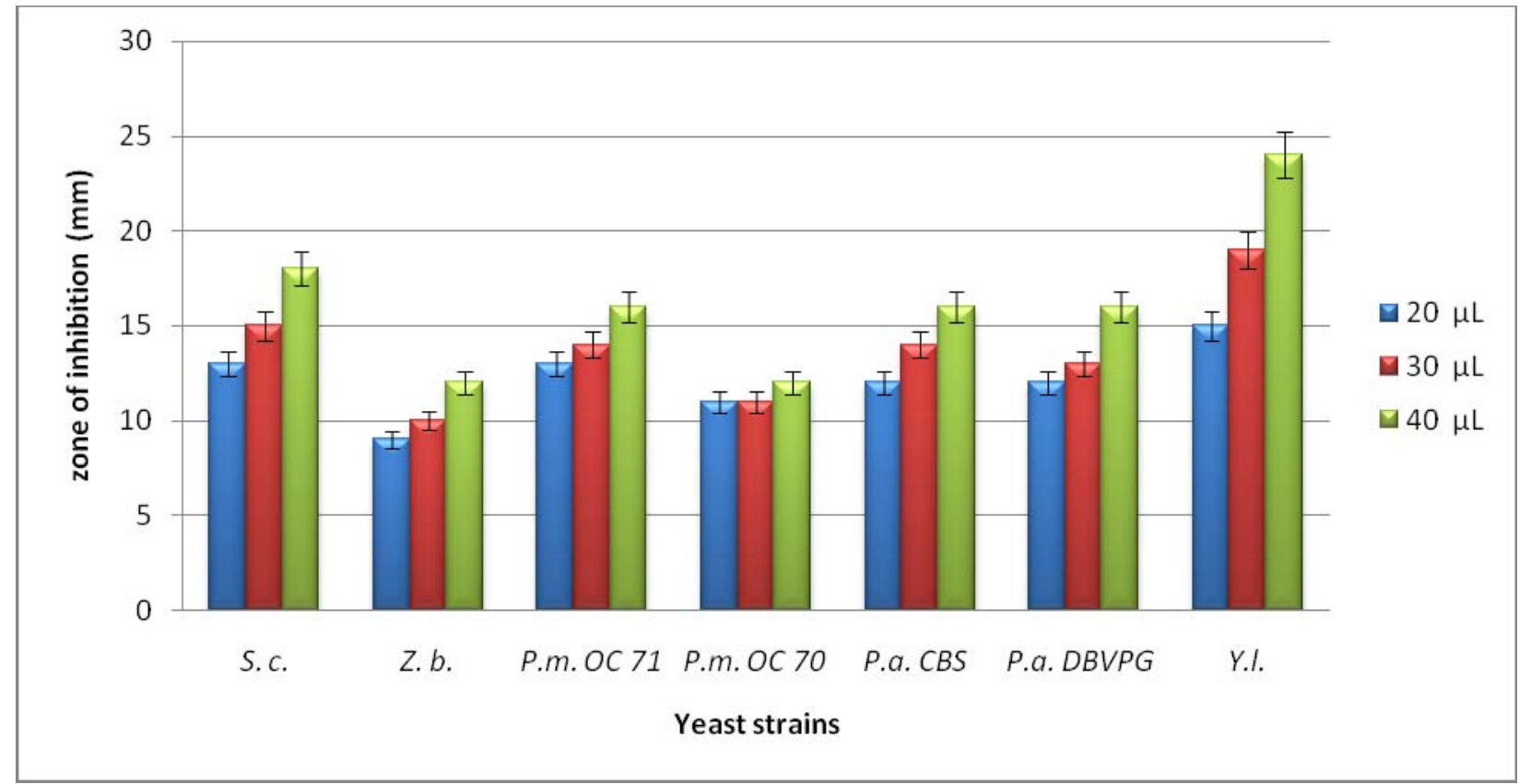

S.c.: Saccharomyces cerevisiae; Z.b.: Zygossaccharomyces bailli 45; P.m. OC71: Pichia membranifaciens OC71; P.m. OC70: Pichia membranifaciens OC70; P.a. CBS 5759: Pichia anomala CBS 5759; P.a. DBVPG 3003: Pichia anomala DBVPG 3003; Y.l.: Yarrowia lipolytica RO13. Column height represents the mean of triplicate results and error bar represents the range of the results. 
Results obtained from disc diffusion method followed by measurements of minimal inhibitory concentration (MIC), confirmed that Y. lipolytica RO13 was the most sensitive microorganism with the highest inhibition zone (24 mm) (Figure 3) and the lowest MIC value $(0.5 \mathrm{mg} / \mathrm{mL})$ (Table 2). The results demonstrated that Porella methanol extract was more effective against the yeast strains than the bacterial ones. The methanol extract of Porella showed the maximum zones of inhibition against yeast $Y$. lipolytica $R O 13$ (15, 18 and $24 \mathrm{~mm})$, followed by $S$. cerevisiae 635 (13, 16 and $18 \mathrm{~mm}$ ) and P. membaranifaciens $O C 71$ (13, 14 and $16 \mathrm{~mm})$, whereas $P$. anomala CBS 5759 and $P$. anomala $B V P G 3003$ showed the same results $(12,14$ and $16 \mathrm{~mm})$. On the other hand, P. membranifaciens OC70 $(11,11$ and $12 \mathrm{~mm})$ and Z. bailli $45(9,10$ and $13 \mathrm{~mm})$ presented the lowest inhibition haloes due to 20,30 and $40 \mu \mathrm{L}$ of Porella extract. Z. bailli was the most resistant yeast (zone of inhibition was $9 \mathrm{~mm}$ ), whereas Y. lipolytica RO13 was the most susceptible also at the lowest concentration tested.

The zones of inhibition detected for bacteria due to $40 \mu \mathrm{L}$ of the methanol extract varied from $11 \mathrm{~mm}$ (E. coli 555) to $17 \mathrm{~mm}$ (L. monocytogenes 56Ly). Results summarized in Figure 2 indicate that L. monocytogenes 56Ly was the most susceptible bacterium for the three volumes of the extract (20, 40 and $60 \mu \mathrm{L}$ ). Based on the results of the chemical composition of the methanol extract it can be concluded that the antimicrobial activity is apparently attributed to its high content of sesquiterpenes and monoterpenes. P. cordaeana extracts are rich in sesquiterpenes hydrocarbons components as caryophyllene, neoisolongifolene, aromadendrene, $\gamma$-muurolene, and monoterpene hydrocarbons such as $\beta$-phellandrene, D-limonene and cymene. The results confirmed that the antimicrobial activity of $P$. cordaeana could be correlated to the presence of $\beta$-phellandrene and caryophyllene. These constituents have been reported to possess significant antimicrobial activity. Caryophyllene showed activity against the microorganisms Escherichia coli, Staphylococcus aureus, Klebsiella pneumoniae, Pseudomonas aeruginosa and Candida albicans [17].

In all the tested extracts $\beta$-phellandrene and caryophyllene were found as the major compounds which could be mainly responsible for the antimicrobial effect of the tested extracts. An antimicrobial activity of caryophyllene has been previously reported $[18,19]$. Plant extracts and essential oils that contain sesquiterpene hydrocarbons are reported to have high antimicrobial activity, and the monoterpenes found in the extract analysed in this work may act as antimicrobial agents [20].

Our results showed that Porella extracts could be used as natural preservative in food or pharmaceutical industries. Several liverworts display antifungal activity [21]. Moreover Porella extracts contain $\beta$-elemene $(3.94 \% ; 2.77 \% ; 1.39 \%$ in methanol, ethanol and ethyl acetate extract, respectively), i.e., compounds which in last recent years are known as strongly novel antitumor agent against ovarium cancer [22] and lung cancer [23]. D-limonene, which is a natural monocyclic monoterpene that has also been detected in significant percentages in all the Porella extracts (3.68\%, $2.93 \%, 3.31 \%$ ), has been shown to possess chemopreventive and therapeutic properties against many human cancers [24].

It is important to outline that the antibiotic cycloheximide, used in comparison with the $P$. cordaeana extracts and endowed with a strong activity against the test strains, is one of the most powerful antimicrobial agents. However, although it is widely used in biomedical research it is not suitable for human use both as therapeutic or antimicrobial agent as its health risks have become better known [25]. The bottleneck of the toxicity against humans and animals of the major part of the antimicrobial molecules or antibiotics delays antifungal discovery. The occurrence of antimicrobial 
compounds, which are known as safe for human consumption, in P. cordaeana could be successfully exploited particularly for the control of food borne yeasts or pathogenic yeasts like Candida albicans.

\section{Experimental}

\subsection{Plant Material}

The samples of Porella cordaeana (Hueb.) Moore were collected in April 2009, locality Zlatar Mt. (Serbia). A voucher specimen (No. 16620) has been deposited in the Herbarium at the Institute of Botany and Botanical Garden "Jevremovac", University of Belgrade (BEOU). Material was dried at room temperature.

\subsection{Extracts Preparation}

Dried plants were pulverized into a fine powder using an electric blender. Powdered material $(10 \mathrm{~g})$ was extracted with methanol, ethanol or ethyl acetate $(100 \mathrm{~mL})$ for $24 \mathrm{~h}$ at room temperature. After $24 \mathrm{~h}$, the mixture was filtered through Whatman No. 1 filter paper. Extracts were prepared on a rotary evaporator (Laborota 4001, Heidolph). The solvent was removed with a rotary vacuum evaporator at $40{ }^{\circ} \mathrm{C}$. The yields of the extracts were $1.23 \%, 0.92 \%$ and $1.06 \%$ for methanol, ethanol and ethyl acetate extract, respectively. The obtained extracts were stored at $4{ }^{\circ} \mathrm{C}$ until further tests.

\subsection{Gaschromatographic (GC)-Mass Spectrometry (MS)-Solid Phase Microextraction (SPME) Analysis}

A divinylbenzene-poly(dimethylsiloxane)-coated stable flex fiber $(65 \mu \mathrm{m})$ and a manual SPME holder (Supelco Inc., Bellefonte, PA, USA) were used in this study after preconditioning according to the manufacturer's instruction manual. Before each headspace sampling, the fiber was exposed to the $\mathrm{GC}$ inlet for $5 \mathrm{~min}$ for thermal desorption at $250{ }^{\circ} \mathrm{C}$ in a blank run.

Samples were put into sealed vials and then equilibrated for $10 \mathrm{~min}$ at $40{ }^{\circ} \mathrm{C}$. The SPME fiber was exposed to each sample for $10 \mathrm{~min}$ by manually penetrating the septum, and, finally, the fiber was inserted into the injection port of the GC for $10 \mathrm{~min}$ sample desorption. GC-MS analyses were carried out on an Agilent 6890 gas chromatograph (Agilent Technologies, Palo Alto, CA, USA) coupled to an Agilent 5970 mass selective detector operating in electron impact mode (ionization voltage, $70 \mathrm{eV}$ ). A Chrompack CP Wax 52 CB capillary column (50 m length, $0.32 \mathrm{~mm}$ i.d., $1.2 \mu \mathrm{m} \mathrm{df}$ ) was used (Chrompack, Middelburg, The Netherlands). The temperature program was $50{ }^{\circ} \mathrm{C}$ for 0 min, then programmed at $5{ }^{\circ} \mathrm{C} / \mathrm{min}$ to $230{ }^{\circ} \mathrm{C}$ for $10 \mathrm{~min}$. Injector, interface, and ion source temperatures were 250, 250, and $230^{\circ} \mathrm{C}$, respectively.

Injections were performed with a split ratio of 1:50 and helium $\left(1 \mathrm{~mL} \mathrm{~min}^{-1}\right)$ as the carrier gas. Identities were confirmed by searching mass spectra in the available databases (NIST, version 2005; Wiley, version 1996) and according to the Registry of Mass Spectral Data (1998) mass spectra libraries as well as literature MS data and in comparison with authentic chemical compounds when commercially available. 


\subsection{Chemicals and Strains}

Different bacterial (Salmonella Enteritidis 155, Escherichia coli 555-Gram-negative and Listeria monocytogenes 56Ly-Gram-positive) and yeast strains (Saccharomyces cerevisiae 635, Zygosacharomyces bailii 45, Aerobasidium pullulans L6F, Pichia membranaefaciens OC 71, Pichia membranaefaciens OC 70 and Yarrowia lipolytica RO13 belonging to the Department of Food Science, University of Bologna, Italy, as well as Pichia anomala CBS5759 and Pichia anomala $D B V P G 3003$ were used to evaluate the effect of plant extracts. The yeasts and bacteria strains used in this study were grown on Yeast Extract Peptone Dextrose (YPD) and Tryptic Soy Broth (TSB) medium, respectively, at $27^{\circ} \mathrm{C}$ for $48 \mathrm{~h}$ (yeasts) and $37^{\circ} \mathrm{C}$ for $24 \mathrm{~h}$ (bacteria). Cells were suspended in sterile distilled water and used immediately.

\subsection{Antimicrobial Assay}

\subsubsection{Determination of Minimum Inhibitory Concentration (MIC) by Microdilution Method}

In order to investigate the antimicrobial activity of the extracts, the modified microdilution technique was used [26,27]. Bacterial species were cultured overnight at $37^{\circ} \mathrm{C}$ in a Tryptic Soy Broth (TSB) medium. Yeast strains were cultured at $27^{\circ} \mathrm{C}$ in YPD medium.

Minimal inhibitory concentrations (MICs) determination was performed by a serial dilution technique using 96-well microtitre plates. The investigated extracts were added in a broth TSB medium (bacteria)/broth YPD medium (yeasts) with inoculum. The microplates were incubated for $48 \mathrm{~h}$ at $37^{\circ} \mathrm{C}$ for bacteria and $72 \mathrm{~h}$ at $28^{\circ} \mathrm{C}$ for yeasts, respectively. The lowest concentrations without visible growth were defined as MIC the MBC (minimal bactericidal concentration)/MFC (minimal microbicidal concentration), indicating (99.5\%) killing of the original inoculums, have been detected. Generally MBC/MFC values are defined as the minimal concentrations of the tested molecule not allowing the microbial growth when $10 \mu \mathrm{L}$ of the cultures taken from the wells with no visible growth are plated onto agarised medium and incubated at the optimial temperatre. Dimethyl sulfoxide (DMSO) was used as an effective extraction solvent, and always used as negative control. All tests were performed in triplicate.

\subsubsection{Disc Diffusion Method}

The following method was used: A portion of each suspension $(100 \mu \mathrm{L})$ containing approximately $10^{5} \mathrm{cfu} / \mathrm{mL}$ was spread over the surface of TSB/YPD plates and allowed to dry. A paper disc (diameter $6 \mathrm{~mm}$ ) was laid on the inside surface of the upper lid and $10 \mu \mathrm{L}$ was placed on each disc. The plates inoculated with microorganisms were immediately inverted on top of the lid and sealed with parafilm to prevent leakage of the vapour. Plates were incubated at $37{ }^{\circ} \mathrm{C} / 27^{\circ} \mathrm{C}$ for $24 \mathrm{~h} / 48 \mathrm{~h}$ and the diameter of the resulting inhibition zone in the bacterial/yeasts lawn was measured. The volume of extracts placed on the paper discs varied, i.e., 20,30 or $40 \mu \mathrm{L}$. A negative control was also included in the test using a filter paper disc saturated with DMSO to check possible activity of this solvent against the bacteria/yeasts assayed. All tests were performed in triplicate. 


\section{Conclusions}

The results of this work demonstrated that $P$. cordaeana extracts possess significant antimicrobial potential against food microorganisms. The methanol extract showed a higher activity compared to ethanol and ethyl acetate ones. High percentages of monoterpene and sesquiterpene hydrocarbons could be responsible for antimicrobial activity. GC/MS-SPME analysis of volatile compounds showed some interesting substances which may prove useful in further investigations for food preservation purposes or as anticancer components.

\section{Acknowledgements}

This research was supported by a grant from the Ministry of Education and Science of Serbia (Project No. 173029) and Department of Food Science, Faculty of Agriculture, University of Bologna, Italy.

\section{References and Notes}

1. Bodade, R.G.; Borkar, P.S.; Arfeen, M.S.; Khobragade, C.N. In vitro Screening of Bryophytes for Antimicrobial Activity. J. Med. Plants 2008, 7, 23-28.

2. Frahn, J.P. Recent Developments of Commercial Products from Bryophytes. Bryologist 2004, 107, 277-283.

3. Asakawa, Y. Chemical Constituents of the Bryophytes. In Progress in the Chemistry of Organic Natural Products; Herz, W., Kirby, W.B., Moore, R.E., Steglich, W., Tamm, Ch., Eds.; Springer: Viena, Austria, 1995; pp. 1-618.

4. Asakawa, Y.; Toyota, M.; Nagashima, F.; Hashimoto, T.; Hassane L.E. Sesquiterpene lactones and acetogenin lactones from the hepaticae and chemo-systematics of the liverworts Frullania, Plagiochila and Porella. Heterocycles 2001, 54, 1057-1093.

5. Chunfeng, S.; Tiantao, Z.; Runhua, L.; Konig, W.A. Essential oil Composition of liverworts Lophozia ventricosa. Chin. J. Appl. Environ. Biol. 2007, 13, 458-460.

6. Hentschel, J.; Zhu, R.I.; Long, D.G.; Davison, P.G.; Schneider, H.S.; Gradstein, R.; Heinrichs, J. A phylogeny of Porella (Porellaceae, Jungermanniopsida) based on nuclear and chloroplast DNA sequences. Mol. Phylogenet. Evol. 2007, 45, 693-705.

7. Toyota, M.; Nagashima, F.; Asakawa, Y. Volatile components and pinguisane-type sesquiterpenoids from the liverwort Porella cordaeana. Phytochemistry 1989, 28, 3383-3387.

8. Asakawa, Y. Recent advances in phytochemistry of bryophytes-acetogenins, terpenoidsand bis(bibenzy)s from selected Japanese, Taiwanese, New Zealand, Argentinean and European liverworts. Phytochemistry 2001, 56, 297-312.

9. Gilabert, M.; Ramos, A.N.; Schiavone, M.; Arena, M.E.; Bardon, A. Bioactive Sesqui- and Diterpenoids from the Argentine Liverwort Porella chilensis. J. Nat. Prod. 2011, 74, 574-579.

10. Harrigan, G.G.; Ahmad, A.; Baj, N.; Glassa, T.E.; Gunatilaka, A.L.; Kingston, D.G.I. Bioactive and other sesquiterpenoids from Porella cordaeana. J. Nat. Prod. 1993, 56, 921-925.

11. Tazaki, H.; Ishikawa, F.; Soutome, H.; Nabeta, K. Grandilobalides A, B and C, sesquiterpenes from the liverwort Porella grandiloba. Phytochemistry 1998, 48, 851-856. 
12. Bungert, M.; Gabler, J.; Adam, K.; Zapp, J.; Becker, H. Pinguisane sesquiterpenes from liverwort Porella navicularis. Phytochemistry 1998, 38, 1079-1083.

13. Nagashima, F.; Izumo, H.; Ishimaru, A.; Momasaki, S.; Toyota, M.; Hashimoto, T.; Asakawa, Y. Africane- and monocyclofarnesane-type sesquiterpenoids from the liverwort Porella subobtusa. Phytochemistry 1996, 43, 1285-1291.

14. van Klink, J.W.; Zapp, J.; Becker, H. Pinguisane-Type Sesquiterpenes from the South American Liverwort Porella recurva (Taylor) Kuhnemann. Pharmakognosie und Analytische Phytochemie Z. Naturforsch. C Biosci. 2002, 57, 413-417.

15. Quang, D.N.; Asakawa, Y. Chemical constituents of the Vietnamese liverwort Porella densifolia. Fitoterapia 2010, 81, 659-661.

16. Ryssel, H.; Kloeters, O.; German, G.; Schafer, T.; Wiedemann, G.; Oehlbauer, M. The antimicrobial effect of acetic acid-An alternative to common local antiseptic? Burns 2008, 35, 695-700.

17. Goren, A.C.; Piozzi, F.; Akcicek, E.; Kılıç, T.; Çarıkçı, S.; Mozioğlu, E.; Setzer, W.N. Essential oil composition of twenty-two Stachys species (mountain tea) and their biological activities. Phytochem. Lett. 2011, 4, 448-453.

18. Costa, E.V.; Teixeira, S.D.; Marques, F.A.; Duarte, M.C.T.; Delarmelina, C.; Pinheiro, M.L.B.; Trigo R.J.; Maia, B.H.L.N.S. Chemical composition and antimicrobial activity of the essential oils of the Amazon Guatteriopsis species. Phytochemistry 2008, 69, 1895-1899.

19. Tyagi, A.K.; Malik, A. Liquid and vapour-phase antifungal activities of selected essential oils against candida albicans: Microscopic observations and chemical characterization of cymbopogon citrates. BMC Complement. Altern. Med. 2010, doi:10.1186/1472-6882-10-65.

20. Hoa, C.L.; Liaoc, P.C.; Wangb, E.I.; Sua, Y.C. Composition and antifungal activities of the leaf essential oil of Neolitsea parvigemma from Taiwan. Nat. Prod. Commun. 2011, 6, 1357-1360.

21. Asakawa, Y. Liverworts-Potential sources of medicinal compounds. Curr. Pharm. Design 2008, 14, 3067-3088.

22. Wang, G.; Li, X.; Huang, F.; Zhao, J.; Ding, H.; Cunningham, C.; Coad, J.E.; Flynn, D.C.; Reed, E.; Li, Q.Q. Antitumor effect of $\beta$-elemene in non-small-cell lung cancer cells is mediated via induction of cell cycle arrest and apoptotic cell death. Cell Mol. Life Sci. 2005, 62, 881-893.

23. Li, X.; Wang, G.; Zhao, J.; Ding, H.; Cunningham, C.; Chen, F.; Flynn, D.C.; Reed, E.; Li, Q.Q. Antiproliferative effect of $\beta$-elemene in chemoresistant ovarian carcinoma cells is mediated through arrest of the cell cycle at the G2-M phase. Cell Mol. Life Sci. 2005, 62, 894-904.

24. Paduch, R.; Kandefer-Szerszeń, M.; Trytek, M.; Fiedurek, J. Terpenes: Substances useful in human healthcare. Arch. Immunol. Ther. Exp. 2007, 55, 315-327.

25. Okoli, I.; Coleman, J.J.; Tempakakis, E.; An, W.F.; Holson, E.; Wagner, F.; Conery, A.L.; Larkins-Ford, J.; Wu, G.; Stern, A.; et al. Identification of antifungal compounds active against Candida albicans using an improved high-throughput Caenorhabaditis elegans assay. PLoS One 2009, 4, e7025.

26. Daouk, K.D.; Dagher, M.S.; Sattout, J.E. Antifungal activity of the essential oil of Origanum syriacum L. J. Food Prot. 1995, 58, 1147-1149. 
27. National Committee for Clinical Laboratory Standards (NCCLS). Performance Standards for Antimicrobial Susceptibility Testing; M100-S9; 9th International Supplement; NCCLS: Wayne, PA, USA, 1999.

Sample Availability: Samples of the dry plants material are available from Dr. Milan Veljic.

(C) 2012 by the authors; licensee MDPI, Basel, Switzerland. This article is an open access article distributed under the terms and conditions of the Creative Commons Attribution license (http://creativecommons.org/licenses/by/3.0/). 